\title{
SER SUJEITO NA ESCOLA
}

Érika Barreira Righi ${ }^{1}$

Este artigo é fruto do trabalho desenvolvido na disciplina Estágio Supervisionado II Anos Iniciais do Ensino Fundamental, do curso de Pedagogia da Unicamp, junto a uma turma de $1^{\circ}$ ano do ensino fundamental de uma escola da rede municipal de Campinas, num processo de aprendizagem de ser professora. Neste contexto, desenvolve-se uma prática docente do aprender brincando, em que o processo de alfabetização se pauta pela percepção de que o aluno que está na escola é, antes, uma criança. $\mathrm{O}$ trabalho da professora é fundamentado em autores como Walter Benjamim e Lev Vygotsky.

A partir da observação, participação, encantamento e reflexão da prática da docente, busquei realizar um projeto de atuação, atividade proposta pela disciplina de estágio, que tivesse os mesmos princípios que o trabalho cotidiano da professora. Então, resultou o projeto "Sentindo o Mundo" em que as crianças, a partir de experiências sensoriais, puderam compreender seu corpo como um elo de ligação com o mundo, conforme Francisco Romão Ferreira (2008).

Estimular o corpo e todos os seus sentidos faz parte da tarefa de educar, pois nosso corpo se forma e é formado também a partir dos estímulos e explorações que recebe e que produz no mundo. Atividades que proporcionem às crianças o papel de um ser ativo, como brincadeiras, atividades diversificadas e experiências vivenciadas, contribuem para a produção de conhecimento e desenvolvimento do seu próprio "eu".

A escola deve ser um lugar que ofereça às crianças a possibilidade de desenvolvimento completo de seu ser, sendo assim, é essencial que seja um ambiente estimulador em que a criança possa explorar seu espaço, ouvir, falar, ver, brincar e vivenciar experiências que produzam conhecimentos e consciência sobre seu próprio corpo, o corpo do outro e como interagem individualmente e coletivamente no mundo.

O conhecimento de seu próprio "eu", ajuda a compreender nosso corpo como um elo de ligação entre o sujeito e o mundo e também como fruto de uma produção social (FERREIRA, 2008).

O corpo se desenvolve como um todo, assim como os estímulos. Por isso, os estímulos não são desenvolvidos de forma separada, e sim a partir de um trabalho integrado: adulto/criança, criança/criança, criança/objeto e com seu meio ambiente, segundo Schiavo e Ribó (2007).

Para Schiavo e Ribó (2007), são quatro tipos de estímulos, essenciais neste processo: Afetivos, Físicos, Cognitivos e Sensoriais.

Nesse projeto de atuação, foquei em trabalhar com as crianças a definição dos estímulos sensoriais através de experiências nas quais se apropriassem dos símbolos pela exploração corporal. Segundo Freire (1978 apud SCHIAVO \& RIBÓ, 2007) não se passa do mundo concreto para a representação mental senão por intermédio da ação corporal. A criança transforma em símbolos aquilo que pode explorar corporalmente: o que ela vê, cheira, pega, chuta, aquilo de que corre e assim por diante. Assim sendo, este projeto de atuação teve como objetivo proporcionar experiências sensoriais para as crianças do primeiro ano, para compreenderem melhor de que forma e como interagem com o ambiente através dos cinco sentidos do corpo humano.

O projeto foi dividido em duas etapas: em um dia trabalhamos os sentidos paladar, olfato e audição e num outro dia trabalhamos tato e visão. Ao final de cada etapa, escrevíamos cartas destinadas à professora de estágio, da Unicamp, para contar-lhe como foram as experiências e o que havíamos aprendido.

\footnotetext{
${ }^{1}$ Universidade Estadual de Campinas.
} 
O tema foi apresentado às crianças apenas através de experiências sensoriais. Não foi dada nenhum tipo de explicação quanto aos cinco sentidos do corpo humano e seus órgãos, toda reflexão surgiu a partir da problematização de como as crianças se sentiram durante as experiências. Em todas as experiências, compartilhamos através da fala e diálogo quais foram os sentimentos e sensações que sentimos. Este momento proporcionou às crianças seu desenvolvimento como ser social a partir do envolvimento com o outro. Aprender a ouvir, falar, se manifestar, fazer comparações, construir seu pensamento e refletir são ações muito importantes que ocorrem no processo de socialização.

Além do projeto, vale ressaltar o trabalho realizado pela professora que me provocou em meu processo de formação. É inevitável: em uma relação sempre há transformação. Ao mesmo tempo o ser transforma-se e é transformador, existindo nessa relação a construção de um ser social e cultural. Diante disso, a escola tem papel essencial na formação humana, pois é lá, depois da família, que começam a ocorrer as primeiras relações com o outro, os conflitos, as alegrias e as tristezas do convívio social. Por isso, a escola deve levar em conta as diferenças, combatendo a desigualdade e assegurar a apropriação e a construção de conhecimentos (KRAMER, 2013).

Em meio a esses novos aprendizados e desafios, está o professor. Este deve prezar pelo bom convívio e pela formação humana. É preciso deixar que as crianças brinquem, aprendam a resolver seus problemas, a valorizar o amigo, a refletirem e etc. Essas ações só se aprendem praticando, errando e acertando. É preciso permitir o desenvolvimento saudável no ambiente escolar e uma relação de confiança com os alunos. Muitas vezes, o professor é a única pessoa em que o aluno pode confiar naquele momento.

Educar é permitir ao outro possibilidades de potencialização de um gênero humano em excelência, por esse motivo, é uma profissão que traz consigo grande responsabilidade. Junto com a prática pedagógica e a tarefa de trabalhar com a turma conhecimentos acumulados social e culturalmente, é preciso assumir, na escola, o indivíduo como sujeito criativo e sujeito cultural.

Segundo Kramer (2013), o conhecimento é um patrimônio cultural e todos são construtores, é fruto de uma relação coletiva e contínua, por isso, apesar de cada um ter seu próprio tempo de aprendizagem, o professor não deve se eximir de seu papel de oferecer estímulos para que a criança vá além do nível em que se encontra e também produza conhecimento.

Deve-se pensar em uma prática em que a dimensão político-social da criança seja valorizada. Atividades coletivas, espaços de reflexão e posicionamento contribuem para essa formação político-social. É preciso compreender que o compromisso com os sujeitos que compõem a sociedade vai muito além dos conhecimentos acumulados socialmente, não podemos limitar o papel da escola apenas a isso.

E nesta vivência do estágio conheci a prática de uma professora com esses princípios. Vivenciei de perto uma prática possível de educação que se concebe como resposta responsável, pois garante o conhecimento do mundo e o reconhecimento do outro. Aprender brincando ou fantasiando o mundo da escola, é a expressão que uso para descrever o que acontecia naquela sala com dezenove crianças e uma professora Robô vinda diretamente do "planeta" Sedna, planeta inventando pela professora para brincar com a imaginação das crianças. Além disto, a sua cumplicidade na relação com as crianças e compreensão de suas inquietações no contexto escolar me chamou a atenção para a constituição das potencialidades do trabalho na escola. Esta brincadeira não se dissociava da produção do conhecimento e parece-me que ela se tornava fator essencial para aumentar a vontade de aprender e descobrir daquelas crianças em sala de aula, no parque e em qualquer lugar. Os momentos de aprendizagem, pelo vivido no estágio, não se resumiam nem se limitavam à sala de aula: podia ser numa visita à casa de um amigo da classe para conhecer onde ele mora, sua família e seus costumes - uma prática frequente para aquela turma, por exemplo. 
Conhecer e estar nesse ambiente, como em toda relação social, transformou-me. Tanto que, para realizar o meu projeto de atuação "Sentindo o Mundo", procurei assumir a mesma postura da professora: ensinar e aprender através das vivências e experiências. Não só no meu projeto de atuação, mas também em minha prática em aprender a ser professora, procurei enxergar o aluno em suas múltiplas dimensões, e não só vê-lo como alguém para quem devese "passar" conhecimentos, mas sim um sujeito com quem se possa construir conhecimento, um sujeito que traz uma história e cultura consigo.

\section{Referências}

FERREIRA, F. R. A produção de sentidos sobre a imagem do corpo. Interface, Botucatu, v. 12, n. 26, p. 471-483, set. 2008.

KRAMER, S. A educação como resposta responsável: apontamentos sobre o outro como prioridade. Belo Horizonte: Autêntica Editora, 2013.

\section{Sobre a autora}

Érika Barreira Righi é estudante do curso de Pedagogia da Faculdade de Educação da Universidade Estadual de Campinas - FE/UNICAMP.

E-mail: erika.righi@hotmail.com. 